\title{
A FALSA LIBERDADE DO CIDADÃO DIANTE DO DIREITO FUNDAMENTAL DO ACESSO À JUSTIÇA
}

\begin{abstract}
Bruna Lustosa Pellegrini
Especialista em Direito Público pela Universidade Anhanguera. Conciliadora da $14^{\text {a }}$ Unidade do Juizado Especial Federal de Fortaleza. Advogada (Unifor) e jornalista (UFC).

Professora tutora da disciplina de Direito Ambiental da Unifor.
\end{abstract}

Sumário: Introdução. 1. Acesso à justiça. 2. O cidadão a sós com a justiça. Considerações finais. Referências.

Resumo: Este artigo visa tratar sobre a relação entre o direito fundamental do acesso à justiça, elencado no artigo $5^{\circ}$, inciso XXXV da Constituição Federal de 1988 e a prerrogativa de liberdade que é dada ao cidadão de impetrar por si próprio uma ação nos Juizados Especiais, nos casos em que o valor da causa não exceda o limite de vinte salários mínimos, sendo dispensada, neste caso, a presença do advogado. Busca-se analisar a fragilidade do discurso da efetivação da justiça sem que se ofereça ao cidadão a real compreensão do seu problema e do direito que lhe assiste, juntamente com a necessidade de um Judiciário consciente de suas funções constitucionais, políticas e sociais. Serão questionadas as causas que obstam a ampliação do acesso do cidadão brasileiro ao Judiciário e a problemática do significado que a concepção jurídica possui diante da comunicação humana dentro de uma realidade que envolve o cidadão comum e os Juizados Especiais, verificando em que medida a linguagem determina a consciência e a compreensão pelo cidadão e em que medida a ideologia do comunicador determina sua linguagem. Tem-se, como objetivo geral, demonstrar que o acesso à Justiça não pode ser entendido simplesmente como o acesso aos tribunais, analisando a capacidade postulatória dada ao popular e o papel do Judiciário numa sociedade despreparada como a brasileira.

Palavras-chave: Acesso à justiça. Liberdade. Cidadão. Judiciário. Relações de poder.

\section{INTRODUÇ̃̃o}

O pensamento jurídico contemporâneo se caracteriza pela luta contra o formalismo e pelo reconhecimento de que a plena compreensão do Direito apenas é possível de maneira concreta e dinâmica. $\mathrm{O}$ mundo do Direito não é restrito aos juristas. Aliás, melhor dizendo, a parte mais interessada nos acontecimentos são o autor e o réu, já que a lide envolve direitos e deveres de cada um. Por isso vamos nos deter na análise de um dos princípios fundamentais intrínseco aos direitos humanos, mas que, na prática, é inferiorizado: o princípio do acesso à justiça pelo homem comum.

Os Juizados Especiais são institutos jurídicos que possibilitam ao cidadão buscar e discutir seus direitos na justiça sem, necessariamente, estar acompanhado por advogado. Essa liberalidade, entretanto, faz com que o homem comum se encontre diante de um embate perante 
o juiz e a parte contrária, juntamente com seu respectivo advogado, além de se ver cercado por todos os rituais, procedimentos, linguagem técnica e comportamento típicos do âmbito jurídico e que são alheios à sua realidade. Será mesmo que há efetiva defesa jurídica para quem não esteja acompanhado pelo profissional do Direito? Como se sente o homem comum diante dessa sua "liberdade"?

A linguagem se materializa de acordo com a ideologia do grupo em que está inserida, utilizando-se do discurso para firmar sua posição e manutenção do poder num determinado contexto social. Ou seja, o discurso é visto como uma forma de dominação.

É o que acontece com o discurso jurídico, que usa uma linguagem excessivamente técnica e complicada para o homem comum, o destinatário final da justiça. A linguagem técnica impede a compreensão real da mensagem, o cidadão permanece indefeso perante seus direitos e há a perpetuação da concentração do poder do discurso nas mãos dos profissionais do Direito.

Deve o homem ser sujeito da sua história, deve ser capaz de transformar seu meio, e isso só é possível àqueles que estão preparados para influenciarem seu ambiente social, o que ocorre essencialmente através da comunicação.

Por isso, torna-se instigante analisar como se dá o processo de comunicação entre o cidadão e o Poder Judiciário, identificando as principais barreiras enfrentadas pelo homem comum para fazer valer seus direitos perante os tribunais e demonstrando que a melhor comunicabilidade (compreensão real de texto e contexto jurídicos) entre o cidadão e o Judiciário aceleraria o andamento dos processos e estimularia a própria sociedade a buscar participar do processo democrático-informativo, tendo em vista que o próprio objetivo da lei e da sociedade é minimizar o papel do discurso e aumentar a ação social produtiva.

\section{Acesso À JustiçA}

O estudo sobre o acesso à justiça deve levar em consideração aspectos que transcendem a visão unicamente jurídica, destacando-se também os aspectos econômico, social, político e educacional. O termo "acesso à justiça" é bastante amplo e, naturalmente, a ele são atribuídas diferentes acepções pela doutrina. Dois desses sentidos adquirem fundamental importância: o primeiro atribui ao significante "justiça" o mesmo sentido e conteúdo que o de Poder Judiciário, e torna sinônimas as expressões acesso à justiça, e acesso ao Judiciário; o segundo compreende o acesso à justiça como o acesso a uma determinada ordem de valores e direitos fundamentais para o ser humano em sociedade.

No presente estudo, vamos nos deter a este último sentido, ao privilegiar o acesso ao Judiciário juntamente com a busca da justiça social e à ordem jurídica justa, pois sua análise não se esgota no acesso aos órgãos judiciais e nem no próprio universo do direito estatal. Assim, explica Nelson Nery Junior (2002) que "não é suficiente o direito à tutela jurisdicional. É preciso que essa tutela seja adequada, sem o que estaria vazio de sentido o princípio".

A definição de acesso à justiça elaborada por Mauro Cappelletti $(2002$, p.8) destaca que:

\footnotetext{
A expressão "acesso à justiça" é reconhecidamente de difícil definição, mas serve para determinar duas finalidades básicas do sistema jurídico - o sistema pelo qual as pessoas podem reivindicar seus direitos e/ou resolver seus litígios sob os auspícios do Estado. Primeiro, o sistema deve ser igualmente acessível a todos; segundo, ele deve produzir resultados que sejam individual e socialmente justos. [...] Sem dúvida, uma premissa básica será a de que a justiça social, tal como desejada por nossas sociedades modernas, pressupõe o acesso efetivo. (grifo original).
} 
Paulo Roberto Medina (2005, p.11) acrescenta:

O acesso à justiça [...] trata-se de um direito social, cujo escopo não é só o de ingressar em
juízo, deduzindo uma pretensão ou formulando uma defesa, mas é também e necessariamente
o de que o jurisdicionado possa receber da justiça tratamento isonômico, uma vez superadas
eventuais desigualdades de armas (isto é, desníveis de ordem econômica) suscetíveis de tornar,
para uma das partes, excessivamente pesado o ônus de alegar e provar os fatos de seu interesse.

Assim, para alcançar o efetivo acesso à justiça, em seu sentido amplo, temos que levar em consideração pressupostos tais como a existência de um direito substancial voltado à efetivação da justiça social, uma administração estatal preocupada com a solução dos problemas sociais e com o integral cumprimento do Direito, o pleno exercício da ação e da defesa e a plenitude da concretização da atividade jurisdicional, sem se esquecer da reestruturação do Poder Judiciário de forma a deixá-lo em sintonia com a sociedade na qual está inserido e adequadamente estruturado para atender às demandas que se lhe são apresentadas.

A Constituição Federal de 1988 (CF/88) trouxe o princípio do acesso à justiça como princípio fundamental, elencado no artigo $5^{\circ}$, inciso XXXV: “a lei não excluirá da apreciação do Poder Judiciário lesão ou ameaça a Direito". Antes mesmo da promulgação da Carta Magna, o jurista italiano Cappelletti (2002, p.12) observou que:

De fato, o direito ao acesso efetivo tem sido progressivamente reconhecido como sendo de importância capital entre os novos direitos individuais e sociais, uma vez que a titularidade de direitos é destituída de sentido, na ausência de mecanismos para a sua efetiva reivindicação. $\mathrm{O}$ acesso à justiça, pode, portanto, ser encarado como o requisito fundamental - o mais básico dos direitos humanos - de um sistema jurídico moderno e igualitário que pretenda garantir, e não apenas proclamar os direitos de todos.

Miguel Reale, entretanto, uma década antes da instituição da $\mathrm{CF} / 88$, já enfocava o problema da socialização do acesso à justiça ao esclarecer que:

A justiça vista apenas como virtude ou vontade de dar a cada um o que é seu, fica-se à
metade do caminho, mesmo porque o seu de cada um somente logra sentido na totalidade
de uma estrutura na qual se correlacionem, deste ou daquele modo, o todo e as partes. Vista,
ao contrário, apenas na sua extrapolação jurídica objetiva, a ordem justa pode ser mera
justa posição mecânica de interesses, segundo critérios de medida impostos à subjetividade
humana, esquecendo-se que esta é a fonte doadora de sentido à validade, a força primordial
que converte em humano tudo aquilo para que se volta a sua intencionalidade (REALE,
1991, p.372).

Ocorre que o direito estatal, enquanto instrumento de controle social e de realização da justiça, tem sido insuficiente e desprovido de efetividade para solucionar os grandes desafios, problemas e conflitos emergentes nas sociedades contemporâneas.

Os problemas históricos e estruturais do Poder Judiciário tornaram-se pragmáticos ao longo dos anos e, de certa forma, acabaram por estar associados às determinações deste Poder, interferindo diretamente na questão do acesso à justiça. São alguns deles: a morosidade existente na prestação jurisdicional; a carência de recursos materiais, humanos e tecnológicos diante da crescente demanda de ações e a falta de condições materiais de trabalho (prédios deteriorados, carência de servidores, excesso de trabalho).

Tudo isso leva a uma série de questionamentos sobre a legitimidade desse Poder, afastando dele muitos conflitos que passam a ser solucionados por uma justiça à margem do ordenamento jurídico estatal, na qual as camadas mais pobres da população buscam a solução 
de seus problemas através da autotutela e da barbárie. São as "justiças das favelas" e os "grupos dos justiceiros", os quais possuem leis e procedimentos próprios, e a presença desses aparatos paraestatais parecem demonstrar a insuficiência dos instrumentos jurídicos formais para concretizarem o ideal de justiça prometido pelo Estado.

De outra banda, a carência de recursos econômicos por grande parte da população para contratar os serviços de um advogado talvez seja o mais grave obstáculo ao efetivo acesso à justiça. Apesar de existir a Defensoria Pública para dar assistência jurídica aos que não podem pagar por este serviço, tal instituição ainda é extremamente insuficiente em algumas regiões (chegando até mesmo a ser inexistente) para atender com qualidade à imensa demanda de brasileiros hipossuficientes.

Cappelletti (2002, p.21) mostra que pessoas ou organizações que possuam recursos financeiros disponíveis têm vantagens óbvias ao propor ou defender demandas:

Em primeiro lugar, elas podem pagar para litigar. Podem, além disso, suportar as delongas do
litígio. Cada uma dessas capacidades, em mãos de uma única das partes, pode ser uma arma
poderosa; a ameaça de litígio torna-se tanto plausível quanto efetiva. De modo similar, uma
das partes pode ser capaz de fazer gastos maiores que a outra e, como resultado, apresentar
seus argumentos de maneira mais eficiente. Julgadores passivos, apesar de suas outras e
mais admiráveis características, exacerbam claramente esse problema, por deixarem às
partes a tarefa de obterem e apresentarem as provas, desenvolverem e discutirem a causa.

Considerando que todas as partes envolvidas possuem formalmente ${ }^{1}$ os mesmos direitos, isso se torna um agravante diante da igualdade que não se concretiza em razão das diferenças sociais, econômicas e culturais entre as partes. Embora todos sejam, teoricamente, livres e iguais para buscarem a realização da justiça, a contradição será mais grave quanto maiores forem as diferenças entre as partes.

Sem igualdade substancial ${ }^{2}$, serão poucas as possibilidades de uma decisão verdadeiramente justa. Seria necessária, segundo Watanabe (1985), a paridade de armas na disputa em juízo, pois não basta ao ser humano o atributo da liberdade se não lhe é dada a própria condição de usufruí-la plenamente.

Nelson Nery Junior aborda a questão da desigualdade econômica e social, e a sua respectiva influência ao acesso à justiça, a partir da visão na maioria das vezes apática do Estado, que acaba por manter o status quo de disparidade entre os homens, mostrando que:

Sem a redução das desigualdades econômicas ao mínimo possível, nenhum mecanismo político ou jurídico permitirá ao homem comum atender às suas necessidades mais básicas e, a partir disso, sonhar em realizar seus desejos e aspirações. O primeiro passo será a melhor distribuição de renda, de modo a evitar a disparidade social clamorosa entre pessoas que o regime atual determina. Para tanto, é indispensável a atuação do Estado como um todo (Executivo, Legislativo e Judiciário) no sentido de evitar, pelo menos, a exploração desmesurada e o lucro exagerado (NERY JUNIOR, 2002, p.45).

1 A igualdade formal prescreve no art. $5^{\circ}$ da $\mathrm{CF} / 88$ a igualdade de todos perante a lei e a proibição de concessão de privilégios de classes entre os cidadãos, podendo, ainda ser compreendida como a pura identidade de direitos e deveres concedidos aos membros da coletividade.

2 Entendida como o tratamento equânime dado aos membros da sociedade, a igualdade material aduz à equiparação dos cidadãos sob todos os aspectos, inclusive o jurídico, com o oferecimento de chances e oportunidades de forma igualitária para todos, respeitadas as diferenças de cada indivíduo e igualando substancialmente o mais fraco ao mais forte. Essa igualdade é a mais almejada e a mais difícil de se concretizar, tendo em vista a prepotente cultura brasileira de extremar as desigualdades materiais e socioeconômicas. A igualdade material é representada pela máxima de Aristóteles, para o qual o princípio da igualdade consistiria em tratar igualmente os iguais e desigualmente os desiguais na medida em que eles se desigualam. 
A desigualdade socioeconômica dificulta o acesso ao Direito e ao Judiciário, o que acaba inferiorizando o próprio cidadão economicamente menos favorecido. A impossibilidade econômica de pagar um advogado acarreta, muitas vezes, uma conduta negativa/omissiva do cidadão com relação ao direito a ser pleiteado, ou uma conduta positiva no sentido de procurar a Defensoria Pública, necessitando enfrentar extensas filas para conseguir atendimento. Ambas as situações findam por desestimulá-lo com relação à luta pelos seus direitos, colocando o mais pobre em nítida situação de desvantagem dentro do processo.

Aragão (1978, p. 81) sintetiza bem todo o problema envolvendo a capacidade postulatória e o acesso à justiça:

\footnotetext{
Nada adiantará que, em teoria, o direito de ação esteja assegurado a todos e os processos se desenvolvam até mesmo com rapidez, se disso não se puderem valer efetivamente todos os interessados. Sob esse ângulo avulta o problema da participação de técnicos na condução do processo. Desde que essa é uma exigência indeclinável de sua realização, pois não está ao alcance de leigos conduzi-lo, forçoso é convir que a assistência desses especialistas - os advogados - não pode ser privilégio: há de estar à disposição de todos quantos deles necessitem.
}

A questão da exigência ou não da presença de advogado em toda e qualquer atividade jurisdicional, olhando sob o prisma do acesso à justiça, mostra que, de um lado, a sua presença aumenta a qualidade e a segurança da defesa dos interesses das partes, tendo em vista a sua formação técnica, enquanto que a maioria da população não tem condições de pagar nem mesmo os honorários do seu patrono.

De fato, a obrigatoriedade da presença do advogado em vários atos da vida jurídica é, ainda, uma realidade do Direito Processual Brasileiro. Reza o artigo 133 da Constituição Federal de 1988 que "o advogado é indispensável à administração da justiça, sendo inviolável por seus atos e manifestações no exercício da profissão, nos limites da lei”.

Entretanto, há situações específicas, como no caso dos Juizados Especiais, que se fosse obrigatória a presença do profissional do Direito nas causas que não excedam vinte salários mínimos (Lei no 9.099, 25 de setembro de 1995 - Lei dos Juizados Especiais Cíveis e Criminais - artigo $9^{\circ}$ ), acabaria por esvaziar sua função social: sendo o valor da causa pouco expressivo, não compensaria, em termos de custo x benefício, reivindicar direitos, caso se tenha de fazê-lo através de advogado, pois em algumas situações os honorários advocatícios seriam maiores ou equivalentes ao valor do próprio bem pleiteado.

De outra sorte, há ainda situações em que se torna necessária a intervenção judicial como mera etapa burocrática, como são os casos de jurisdição voluntária. Nesses casos, não se justifica a exigência de uma atuação simplesmente simbólica do profissional, fruto de um formalismo antipopular, conforme assevera Joaquim Falcão (1988, p. 21):

Para esta 'administração da Justiça' os advogados deveriam ser dispensáveis. Como também deveriam ser nos pequenos conflitos onde os cidadãos são capazes de se defender. Do contrário, confunde-se advogado com tutor. Pior. Subentende-se que todos os cidadãos brasileiros são relativamente incapazes [...] pois os serviços dos advogados são do interesse do povo numa sociedade pluralística e democrática. Mas estes serviços, para serem eficazes, têm de ser legítimos e vai ser difícil convencer o povo da necessidade de advogados onde sua própria experiência cotidiana os demonstra dispensáveis.

Ademais, verificando a última pesquisa realizada pela Ordem dos Advogados do Brasil (OAB), o que precisa ser levado em consideração é que não basta a presença física do 
advogado, é necessário, inicialmente, considerar a sua qualificação profissional, principalmente considerando o já saturado mercado de trabalho e que dos 1.210 cursos de graduação em Direito do país, apenas 90 foram recomendados pela instituição por apresentarem altos índices de qualidade. ${ }^{3}$

$\mathrm{O}$ efetivo acesso à justiça pressupõe também o assessoramento de um bom profissional, no entanto, a baixa qualidade do ensino jurídico oferecido no país (ainda conservador, legalista e reprodutor do status quo) leva a uma má formação intelectual e pessoal dos bacharéis em Direito, além da ampliação da quantidade de cursos nas universidades, que também se diversificaram, o que aumentou o número de alunos sem que houvesse meios materiais e corpo docente qualificado para atender à demanda.

\subsection{O Alcance Social dos Juizados Especiais}

A previsão do instituto dos Juizados Especiais aconteceu com a promulgação da Constituição Federal de 1988, cujo artigo 98, inciso I, enuncia que a União, o Distrito Federal e os Estados poderão criar juizados especiais providos por juízes competentes para conciliação, julgamento e execução de causas cíveis de menor complexidade e infrações penais de menor potencial ofensivo. Entretanto, sua efetiva implantação só veio acontecer em 1995, com a aprovação da Lei Federal no 9.099.

Assim, causas com valor até quarenta salários mínimos puderam ser processadas e julgadas pelos Juizados Especiais Cíveis (JEC), passando a ser facultativa a assistência do advogado nas causas cujo montante não ultrapasse vinte salários mínimos. Dessa forma, os JECs permitiram que pessoas de menor poder aquisitivo pudessem buscar, por si mesmas, a solução para os seus conflitos do cotidiano, o que anteriormente não costumavam ser apreciados pela Justiça brasileira devido à dificuldade do cidadão comum em contratar um advogado para postular a seu favor.

Sem dúvida, a criação dos JECs representou para o cidadão mais um mecanismo de acesso à justiça, cujo objetivo é a resolução de forma rápida e informal de causas consideradas simples, buscando sempre o acordo entre as partes, daí ter suas bases nos critérios da oralidade, da simplicidade, da economia processual e da celeridade.

A informalidade e a simplicidade são marcadas pela desburocratização e, inclusive, pelo fato da limitação do valor da causa (quarenta salários mínimos). Ultrapassando esse valor, infere-se pela complexidade da matéria posta em julgamento, assim como casos que demandam a produção de provas técnicas (perícia), causas de natureza alimentar, falimentar, fiscal e de interesse da Fazenda Pública, bem como aquelas que sejam relativas a acidentes de trabalho, ao estado e à capacidade das pessoas, o que os tornam incompatíveis com os critérios norteadores dos JECs.

\section{O CIDADÃO A SÓS COM A JUSTIÇA}

A prática forense mostra que o cidadão que se sente lesado e busca, sozinho, resolver a pendência no Juizado Especial encontra na maioria das vezes do outro lado da demanda, como ré, grandes empresas muito mais preparadas tecnicamente para o embate, pois seguramente estarão assessoradas por, pelo menos, um advogado.

Chegando sozinho ao balcão do Juizado, o contato inicial é feito com os servidores que fazem o primeiro atendimento e redigem as pretensões do cidadão. Em sua maioria, estão

3 OAB recomenda 90 dos 1.210 cursos de direito do país. O Estado de São Paulo, Curitiba, 23 nov. 2011. Disponível em: $<$ http://www.estadao.com.br/noticias/vida,oab-recomenda-90-dos-1210-cursos-de-direito-do-pais,802016,0.htm>.

Acesso em: 15 abr. 2012. 
ali apenas para escrever o que o cidadão venha a falar, pouco se importando em elaborar uma petição eficaz ou alertar sobre os direitos que podem ser pleiteados. O segundo contato vem com os conciliadores, que algumas vezes são despreparados e não se empenham para que as partes entrem em acordo. O terceiro contato se dá com os magistrados.

Ao juiz, enquanto magistrado, cabe ajustar a lei à realidade social, a ela não se subordinando nem se aprisionando, mas devendo sentir o que o povo sente, não se ausentando do mundo para ser mero aplicador da lei. Captando todos esses sentimentos, o juiz deveria traduzir o direito da forma mais clara, para que o cidadão pudesse compreender instantaneamente. Mas, de fato, sabemos que essa sensibilidade e essa consciência estão distantes da grande parte dos julgadores, principalmente dos mais tradicionalistas.

Quando o autor formula sua reclamação nos balcões do Juizado, será apenas sobre o que ele expõe que irão girar todos os demais questionamentos. Não poderá questionar nada além do que foi inicialmente pedido e, nesse caso, um pedido mal elaborado ou incompleto não garante a conquista da plenitude dos direitos do cidadão.

Assim, quando o processo é julgado improcedente, negando o que o autor, cidadão comum, tinha como certo e justo, este busca o auxílio do técnico - advogado - que, então, tem pouco ou quase nada a fazer, tendo em vista que o processo já foi julgado e o recurso que porventura venha a caber possa não ser eficaz:

O autor fica à mercê daquele que eventualmente domine a técnica processual. (...) Há fatos que resultam em nada por não ter sido formulado o necessário pedido, tampouco exposto o necessário fundamento. (...) Os fatos são a única coisa segura que o autor sabe com minúcias e que não requerem maiores requintes técnicos na exposição. O outro elemento da causa de pedir e o pedido reclamam um conhecimento técnico. (CHIMENTI, 2003, p.185)

Após a sentença desfavorável, deve o autor procurar os serviços de um profissional do Direito, e o faz justamente por se sentir traído ao confiar que poderia buscar sozinho seu direito. Chimenti (2003, p. 186) não deixa de lembrar também:

É bem verdade que o parágrafo segundo do artigo $9^{\circ}$ da lei impõe ao julgador o dever de alertar as partes quando a causa recomendar o patrocínio do advogado. Sucede que a primeira oportunidade em que o julgador pode vir a tomar contato com o autor e sua pretensão é na audiência de instrução e julgamento naquelas comarcas em que existe a figura do conciliador para tentar a conciliação. Este momento, processualmente, não autoriza modificação ou aditamento ao histórico inicial apresentado, a não ser que conte com a concordância do pólo passivo.

O procedimento dos Juizados Especiais deixa de ter uma imagem formalista, com a presença obrigatória do advogado, que é próprio do procedimento comum, para reverter-se como um meio hábil, rápido à obtenção da justiça, e essa simplificação das formalidades e a desburocratização o torna mais simpático ao cidadão comum, que muitas vezes se sente intimidado diante de determinadas formas de manifestação do poder.

Tal imagem, aliada à cultura brasileira de se "automedicar", achando sempre uma forma de resolver por si só o problema, sem a ajuda de profissionais especializados, pode representar num primeiro momento economia de dinheiro, mas não implica necessariamente domínio da situação e efetividade de defesa. Até porque os profissionais do Direito, principalmente advogados e juízes, se utilizam das técnicas argumentativas para alcançarem seu alvo: a persuasão do interlocutor. 


\subsection{O Discurso Jurídico}

O discurso jurídico se dirige normalmente apenas às partes interessadas, aos advogados $\mathrm{e}$ ao juiz julgador. Durante a tramitação de um processo, as partes quase não interagem. Os enunciadores são os juízes e advogados, que possuem habilidades específicas adquiridas após um curso superior. São textos em que o espaço para a criatividade é pequeno, uma vez que possuem características e linguagem bastante específicas e devem estar adstritos ao que está disposto na legislação vigente.

Enquanto os advogados devem usar o poder da argumentação para convencer o juiz de que o direito de seu cliente é plausível e foi violado, o que torna seu texto bastante subjetivo, tendo em vista que cabe a cada parte defender seu próprio ponto de vista a respeito do problema apresentado, de outra banda os textos dos juízes devem ser os mais neutros possíveis, para não comprometer a sua imparcialidade quanto ao julgamento da causa, analisando qual dos pontos de vista apresentados está de acordo com o ordenamento vigente, expondo sua decisão de modo a convencer seus interlocutores.

Daí, conclui Luciana Morilas (2001, p.326):

Assim, não é próprio apenas dos advogados o texto argumentativo com vistas à persuasão mas também dos juízes, que devem obrigatoriamente apresentar suas decisões de forma motivada para convencer todos os seus interlocutores de que a razão lhe assiste, ou melhor, de que sua decisão é a mais acertada.

Pode-se inferir também que a própria realidade pode ser forjada com palavras, pois aquele que souber apresentar seu ponto de vista de um modo mais convincente é o que terá a sentença julgada favorável a seu favor. Daí a importância da assessoria do advogado para que o cidadão comum, muitas vezes leigo e inexperiente, não seja ludibriado pelo simples fato de poder ir sozinho buscar defender seus direitos no Juizado.

O discurso é uma forma de agir sobre o mundo e dele surgem as disputas de relação de poder. O contexto deve ser considerado para que se possa atentar para a posição dos seus participantes e Bakhtin (1997) enxerga a linguagem como um constante processo de interação mediado pelo diálogo, sofrendo influências do contexto social, da ideologia dominante e da luta de classes:

A classe dominante tende a conferir ao signo ideológico um caráter intangível e acima das diferenças de classes, a fim de abafar ou de ocultar a luta dos índices sociais de valor que ai se trava, a fim de tornar o signo monovalente (BAKHTIN (1997, p. 47).

A interação verbal é um evento de construção de sentidos e de relações sociais, de identidades que se configuram em relação às imagens mútuas construídas ao longo da interação, visível à luta de sujeitos para demarcar seus lugares e de onde emerge o conflito na construção das relações de poder instauradas no mundo social (o profissional do direito impõe poder e prestígio, em contrapartida o homem comum, parte no processo, acaba se tornando "submisso" diante da sua "ignorância" jurídica).

Nesse sentido, Luciana Morilas (2001, p. 327) defende que "qualquer argumentação que se queira eficiente deve, antes de tudo, preocupar-se com o interlocutor, com seus valores, ou seja, deve conhecer profundamente o outro e estabelecer com ele uma interação positiva".

Toda formação social tem formas de controle da interpretação e há um corpo social, tais como juízes e advogados, a quem se delegam "poderes" de interpretar, atribuir sentido. Assim, a linguagem pode servir para comunicar e para não comunicar, dependendo da intenção que se queira atingir. 
Como já esclarecido, Bakhtin chama atenção para o fato de que o discurso verbal não pode ser compreendido fora da situação social que o concebe, não existindo isoladamente.

Foucault aborda a relação entre o discurso e o poder, no viés de que a manutenção do poder pelas instituições acontece através do controle de discursos. O controle externo, chamado de sistema de exclusão, prevê procedimentos que obstam a criação do discurso, pressionandoos para que não sejam enunciados. Ou seja, o discurso é visto como uma forma de dominação.

Pode suspeitar-se que há nas sociedades, de um modo muito regular, uma espécie de desnível entre os discursos: os discursos que "se dizem" ao correr dos dias e das relações, discursos que se esquecem no próprio acto que lhes deu origem; e os discursos que estão na origem de um certo número de novos actos de fala, actos que os retomam, os transformam ou falam deles, numa palavra, os discursos que, indefinidamente e para além da sua formulação, são ditos, ficam ditos, e estão ainda por dizer. Sabemos da sua existência no nosso sistema de cultura: são os textos religiosos ou jurídicos. (FOUCAULT, 2003, p. 19)

É o que acontece com o discurso jurídico, que usa uma linguagem excessivamente técnica que impede a compreensão da mensagem pelo cidadão e concentra poder do discurso nas mãos dos profissionais do Direito. Os sistemas de exclusão englobam determinados assuntos que não podem entrar no discurso, determinados discursos que só podem ser anunciados em certas ocasiões e por determinados sujeitos, oposição entre a razão e a loucura e aparência de verdade do discurso.

\begin{abstract}
A forma mais superficial e mais visível destes sistemas de restrição é constituída por aquilo que se pode agrupar sob o nome de ritual ; o ritual define a qualificação que devem possuir os indivíduos que falam (e que, no jogo do diálogo, na interrogação, na recitação, devem ocupar determinada posição e formular determinado tipo de enunciados) ; define os gestos, os comportamentos, as circunstâncias e todo o conjunto de sinais que devem acompanhar o discurso ; o ritual fixa, por fim, a eficácia, suposta ou imposta, das palavras, o seu efeito sobre aqueles a quem elas se dirigem, os limites do seu valor constrangedor. Os discursos religiosos, jurídicos, terapêuticos, e em parte também os políticos, não são dissociáveis desse exercício de um ritual que determina para os sujeitos falantes, ao mesmo tempo, propriedades singulares e papéis convenientes. (FOUCAULT, 2003, p. 21)
\end{abstract}

Os aplicadores do Direito são os maiores emissores e receptores das leis. O legislador, em nome do povo, dá origem às leis, os juízes interpretam e aplicam ao caso concreto, devendo transmitir a essência do Direito e se fazerem entender. As partes, como receptores, devem decodificar a mensagem emitida pelos juízes e produzirem uma resposta à mesma. Só então a comunicação terá sido estabelecida. Só assim a mensagem foi passada. Da mesma forma, as partes devem se manifestar de maneira tal que os aplicadores do Direito possam entender os seus anseios e se comunicarem de forma eficaz.

No entanto, deve o juiz analisar que não pode estar alheio às diferenças sociais, econômicas, culturais e políticas das partes e da sociedade em que vive. O juiz deve se colocar dentro da realidade social e identificar as forças que produzem o direito, para estabelecer a relação entre esse direito e a sociedade, devendo sempre questionar a legitimidade da norma, para adequála à realidade social.

\title{
2.2 Fatores de (IN)Comunicação
}

A efetividade do acesso à justiça exige, igualmente, a existência de instrumentos processuais acessíveis e céleres na resolução dos conflitos de interesses, o que acarreta, 
consequentemente, a necessidade de adoção de medidas capazes de acelerar o andamento dos processos levados ao Judiciário.

Sálvio de Figueiredo Teixeira (1993 p.92), preocupado com alguns formalismos e atitudes protelatórias presentes no ordenamento afirma que:

É de convir-se [...] que somente procedimentos rápidos e eficazes têm o condão de realizar o verdadeiro escopo do processo. Daí a imprescindibilidade de um novo processo: ágil, seguro e moderno, sem as amarras fetichistas do passado e do presente, apto a servir de instrumento à realização da justiça, à defesa da cidadania, a viabilizar a convivência humana e a própria arte de viver.

O nível de desinformação da população é muito grande com relação à legislação vigente. Isso se deve, principalmente, por causa do sistema educacional, dos meios de comunicação e da inexistência ou insuficiência de instituições oficiais encarregadas de prestarem a assistência jurídica preventiva e extrajudicial.

O conhecimento dos direitos por parte do cidadão e da sociedade é pressuposto ao efetivo acesso à justiça. Dessa forma, sem a existência de órgãos que possam ser consultados pela população quando houver dúvidas jurídicas sobre determinadas situações de fato, e ficando o cidadão sem a imediata resposta aos seus anseios, a possibilidade da plena efetividade do Direito se torna acanhada.

A informação é peça fundamental para a comunicação do homem em sociedade, pois a partir dela ele pode expressar suas críticas, buscar soluções e ser compreendido pelo outro e pelo próprio Estado, contribuindo para que a máquina estatal se utilize dos mecanismos de solução de conflitos que lhe são inerentes.

Relacionando o processo de comunicação com o ambiente jurídico, frequentemente encontramos os operadores do Direito (juízes, promotores, procuradores, defensores e os próprios advogados) envolvidos num "mundo" alheio às partes.

Os níveis de habilidade comunicativa dos seres humanos determinam de duas formas a fidelidade da comunicação. Primeiro, influenciam a capacidade de analisar os próprios objetivos e intenções, de dizer alguma coisa no ato de comunicar. Segundo, influenciam a capacidade de codificar mensagens que exprimam o que se pretende efetivamente exprimir.

Ou seja, o juiz deve ter a exata ciência do seu papel de comunicador entre as partes, devendo ter o cuidado de ser corretamente compreendido, já que seu objetivo é mostrar o direito para aqueles que estão em litígio.

Um juiz deve analisar cada caso separadamente, levando em conta tudo o que circunda os fatos. Dessa maneira, deve conhecer o meio em que o réu vive, suas condições financeiras, sua cultura, escolaridade e o que for possível, para que a decisão seja o mais compatível possível com o caso em questão. (MORAIS; OLIVEIRA, 1998, p. 43)

Mauro Wolf (1995, p.12) destaca a importância da efetividade da comunicação e o estímulo que ela pode causar às pessoas:

Se aqueles que manifestam interesse sobre determinado assunto, o fazem depois de a ele terem sido expostos, aqueles que demonstram desinteressados e desinformados fazem-no porque nunca foram expostos à informação referente a esse mesmo assunto. Quanto mais expostas as pessoas são a determinado assunto, mais o seu interesse aumenta e, à medida que o interesse aumenta, mais as pessoas se sentem motivadas para saberem mais acerca dele. 
As atitudes da fonte para com o receptor influenciam a comunicação. Quando os destinatários da mensagem percebem que o emissor apresenta empatia e há interação, mostram-se muito menos críticos quanto à mensagem e muito mais propensos a aceitar o que ele diz. Assim acontece, por exemplo, quando juízes tentam abrir o diálogo entre as partes, quando as olha no olho, de frente, e não sob o manto "intocável” da toga, que bloqueia a captação pelo transmissor de qualquer efeito regressivo, já que não abre possibilidade, para o retorno.

Para transmitir a mensagem, é necessário ter o vocabulário adequado para revelar as ideias, usando palavras que expressem com a maior clareza o sentido a ser repassado - a fim de que o receptor possa decodificá-las com facilidade. Escrever "corretamente" apenas para cumprir as leis da grafia ou do vocabulário culto acaba por interferir na recepção da mensagem pelo homem comum. Ao falar, é preciso saber como pronunciar as palavras, como gesticular, como interpretar as mensagens no decorrer do discurso. A comunicação ideal é aquela que codifica mensagens que tenham boas possibilidades de serem corretamente decodificadas, de forma que fique claro o pensamento de quem está emitindo.

Muitos juízes, defensores públicos e advogados esquecem que o seu objetivo original é se fazerem entendidos para as partes, buscando a maior nitidez e esclarecimento de seus direitos - ficam por demais ocupados em "dramatizar" o Direito ou em pronunciar expressões eruditas ou em latim. Deixam de se colocar na posição de parte e se concentram em "parecer" donos do saber e, consequentemente, incontestáveis. Para Morais e Oliveira (1998, p. 153),

No exato instante da oferta da prestação jurisdicional, exerce o magistrado sua função precípua de dizer o direito que deve reger aquela lide, geralmente esgotando sua intervenção. Sobretudo, cumpre ao juiz ater-se aos fundamentos de sua decisão, procurando imprimirlhe eficácia social, isto é, capacidade de transformação da realidade.

Tais prioridades e inversões de valores acabam por ocasionar colapsos na comunicação, falha esta que resulta na forma de absorver o conteúdo pelo receptor da mensagem.

O conhecimento da fonte sobre o assunto também influencia na mensagem. Ninguém é capaz de comunicar aquilo que não sabe; ninguém comunica com a máxima efetividade material que não conhece. De outro lado, se a fonte sabe “demais", se é ultra-especializada, poderá errar pelo fato de suas habilidades comunicadoras serem empregadas de maneira tão técnica que o receptor acabe não entendendo.

Ada Pellegrini Grinover (1990, p.18) aponta alguns dos principais problemas que contribuem para a crise da mentalidade do julgador:

[...] o esquema burocrático e verticalizado da magistratura brasileira, [...] o próprio método de recrutamento dos juízes, a inocorrência, até pouco tempo atrás, de cursos de aperfeiçoamento e especialização para os membros do Judiciário, o distanciamento dos julgadores, que tem reflexos até mesmo na linguagem, tudo isto tem levado, no curso dos tempos, ao excessivo corporativismo dos juízes, encastelados em posições de gabinete que pouco ou nada têm a ver com a realidade de uma sociedade em transformação. Eis a razão pela qual poucos magistrados têm se demonstrado sensíveis aos desafios criados pelos novos tempos e nem todos têm sabido dar as necessárias respostas a conflitos diversos dos tradicionais, a serem solucionados por instrumentos processuais antes inexistentes, esboçados pela Constituição de 1988 e, em alguns casos, por leis recentes.

O conhecimento do processo de comunicação por si só influencia o comportamento da fonte. Como afirma Berlo (1997; p. 56), "O conhecimento da comunicação influencia o comportamento de comunicação". O comportamento de comunicação é influenciado pelo 
quanto a fonte sabe sobre as próprias atitudes, sobre as características do receptor, sobre os meios pelos quais poderá produzir ou tratar as mensagens, sobre as várias escolhas que poderá fazer de canais de comunicação, etc. A fonte precisa conhecer o tema. Precisa saber também como ensiná-lo efetivamente.

Os sistemas social e cultural determinam em boa parte as escolhas de palavras que as pessoas fazem, os objetivos que têm para comunicar, os meios e formas que usam para esta ou aquela espécie de mensagem, com relação ao receptor/parte. A fonte/juiz cumpre muitos papéis e tem percepções ou imagens variáveis sobre a posição social e cultural do receptor.

Estas percepções influenciam o seu comportamento de comunicação. Por exemplo: o juiz pode e deve falar de um modo ao dirigir-se a um grupo de advogados, defensores e promotores (aplicadores do Direito), e de outro diametralmente inverso quando aos litigantes, que são cidadãos muitas vezes ignorantes com relação às leis e deficientes em termos de conhecimento ou integrantes de culturas diferentes e socialmente desprestigiadas. Os primeiros conhecem a técnica jurídica, expressões peculiares à ciência. Os últimos necessitam de maior atenção, objetividade e clareza na comunicação.

Como observa Heliana Maria de Azevedo Coutinho (1998, p.95):

\begin{abstract}
Muitas vezes, os juízes mais conscientes das injustiças sociais decorrentes tanto da ineficiência da legislação (material e processual) de nosso ordenamento jurídico quanto da burocracia cartorial procuram alternativas na simplificação das formas e nos Princípios do Direito para flexibilizar a interpretação das normas, aplicando-as de modo mais adequado e justo aos casos concretos. O juiz que funciona como agente político tem buscado maior aproximação com a população, objetivando manter a credibilidade e o prestígio da Instituição e o fortalecimento da legitimidade do poder jurisdicional, com decisões respeitadas e materialmente exequíveis no seio da sociedade.
\end{abstract}

É preciso conhecer o contexto cultural no qual se comunica, as crenças e os valores culturais que lhe parecem dominantes, as formas de comportamento aceitáveis ou não aceitáveis, exigidas ou não exigidas em sua cultura, além das suas expectativas tanto como as de outros a seu respeito. Continua a mesma doutrinadora:

Não se concebe hoje seja o juiz indiferente às mudanças sociais, continuando a adotar postura positivista e legalista, sem tomar consciência de que está em suas mãos a responsabilidade e o poder de extrair das normas constitucionais o significado válido e atual para interpretar outras leis, ou mesmo afastá-las de aplicação, na solução de um caso concreto (COUTINHO, 1988, p.45).

O status social do cidadão litigante, os componentes do seu grupo, suas formas habituais de conduta, influenciam os modos pelos quais recebe e interpreta as mensagens. A única justificação para a existência da fonte, para a ocorrência da comunicação, é o receptor, o alvo ao qual tudo é destinado:

Assim sendo, sentida a carência de elementos de subsistência material, que dizer da justiça, transformada em verdadeiro artigo de luxo, acessível a alguns poucos que lutam por ela e estão conscientizados dos seus direitos. Aquele que mais carece da presença do agente estatal, aquele que é analfabeto, desempregado, miserável, desconhecedor dos direitos que lhe assistem, embora continuadamente violados, não sabe como recorrer às instâncias cabíveis. E quando sabe, desacredita na sua eficácia, pois não compreende o porquê de tantos papéis, tantos documentos e, sobretudo, tanta demora (MORAIS; OLIVEIRA, 1998, p. 171). 
Heliana Maria de Azevedo Coutinho (1998, p. 161) ressalta ainda:

O juiz assume uma função instrutória e integrativa, orientando a participação da discussão entre as partes, na busca de solução do conflito. Age, assim, como formador de opinião, direcionador de condutas sociais das massas e educador do cidadão que busca, na justiça, a solução de seus problemas, colocando-se em posição não de autoridade repressora e executora de regras sociais impostas, mas de informadora do direito e dos deveres inerentes à cidadania.

Quando o juiz escolhe a forma de transmitir a sua mensagem, deve escolher aquela que acha ser a mais íntima e rotineira do receptor. Quando seleciona o conteúdo, a fim de refletir seu objetivo, seleciona um conteúdo que tenha significação para o receptor, chame sua atenção, a fim de minimizar o esforço requerido para decodificar e interpretar a mensagem. Quando trata a mensagem de alguma forma, parte desse tratamento é determinado pela sua análise das habilidades de comunicação (decodificação) do receptor, de suas atitudes, conhecimentos e posição no contexto sociocultural.

Esses são alguns dos aspectos que fazem com que as partes acabem por perceber erroneamente a resposta que os aplicadores do Direito pretendem produzir e o verdadeiro objetivo da comunicação poder estar diferente daquele que é percebido como tal por quem o executa.

\section{CONSIDERAÇÕES FINAIS}

As questões relacionadas à efetividade do acesso à justiça integram-se definitivamente ao cumprimento da função social do Estado contemporâneo preocupado com a realização da justiça social. Foi com a promulgação da Constituição do Brasil de 1988 que os problemas do acesso à justiça começaram a ser discutidos com maior evidência, em busca de soluções inerentes à eficaz assistência jurídica aos carentes, à maior divulgação de informações ao cidadão e à legitimidade para agir. Novos instrumentos processuais para a garantia dos direitos individuais e coletivos foram criados, acarretando uma nova concepção estrutural ao Poder Judiciário.

Os Juizados Especiais foram criados com o intuito de dar maior autonomia ao cidadão e celeridade ao processo; entretanto, a prática sinaliza que o cidadão sente-se desprotegido e indefeso se não estiver acompanhado por um advogado, pois não sabe como exercer seu direito, quais os procedimentos a serem tomados, desconhece a legislação relativa ao seu caso e não compreende a mensagem jurídica, com seus inúmeros termos técnicos que mais parecem ser utilizados para legitimar o poder dos operadores judiciários.

Entretanto, não se pode ter um efetivo acesso à justiça sem profissionais devidamente qualificados e, naturalmente, não pode haver profissionais qualificados sem um bom nível de ensino, deixando de observar os problemas sobre o acesso à justiça apenas como casos a serem resolvidos através de criação de novos instrumentos técnico-processuais ou da correção dos existentes, o que auxilia na manutenção e reprodução do status quo. É preciso que o sistema processual seja visto como instrumento de solução de conflitos e, fundamentalmente, como instrumento político de realização da justiça social.

Somente com aplicadores do Direito conscientes, sabedores da realidade política, econômica, cultural e sociológica da realidade brasileira e esclarecidos quanto à dignidade da arte de aplicar o Direito, é que suas decisões serão mais adequadas ao mundo atual e, consequentemente, mais justas. 
A falta de instrução e a deficiente informação geram a dominação. De fato, a razão será dada àquele que souber trabalhar seus argumentos com maior potencial retórico. Para isso, é necessário conhecer as técnicas argumentativas e também as opções que a língua oferece para que se mostre um mesmo fato de um modo ou de outro. Sabe-se, entretanto, que o cidadão comum e o estudioso do Direito encontram-se em completo desequilíbrio na hierarquia social, cultural e política.

Torna-se difícil achar mecanismos efetivamente viáveis para construir uma realidade comunicativamente democrática quando se tratam de questões envolvendo ideologia e poder. A realidade judiciária brasileira fez necessária a instalação de juizados especiais como uma forma de tornar a justiça mais próxima ao cidadão. Se a lei permite que o homem comum possa lutar sozinho por seus direitos no JEC, por exemplo, que sejam formados cidadãos que estejam seguros e preparados para elaborar essa defesa de forma efetiva e real.

A fórmula de democratização da justiça é aproximá-la do povo, principalmente dos mais carentes, que têm fome e sede de justiça, a começar pela própria situação de extrema desigualdade que sofrem com a falta de distribuição de renda. Adotar mecanismos para incluir os mais necessitados no acesso à justiça estimula nossa frágil democracia e resgata a cidadania.

Esperamos que, um dia, todos os Estados garantam eficazmente a plena liberdade de expressão e ação, dentro dos limites estabelecidos pela própria sociedade ou por ela referendados, não encobrindo as contradições e a pluralidade inerentes a qualquer agrupamento humano, sendo estruturados segundo um modelo de organização social que assegure a todos os seus membros uma existência digna e saudável, caracterizada pelo suprimento de suas necessidades básicas e pela existência de condições concretas de sua realização enquanto pessoa humana.

\section{REFERÊNCIAS}

ARAGÃO, Egas Dirceu Moniz de. O estado de Direito e o direito de ação (a extensão do seu exercício). Rev. Bras. de Dir. Processual. Rio de Janeiro: Forense, 1978.

BAKHTIN, Mikhail Mikhailo. Marxismo e filosofia da linguagem. 8. ed. São Paulo: Hucitec, 1997.

BERLO, David K. O processo da comunicação: introdução à teoria e à prática. São Paulo: Martins Fontes, 1997.

BOBBIO, Norberto. Teoria do ordenamento jurídico. 4. ed. Brasília: Ed. Universidade de Brasília, 1994.

BRASIL. Constituição da República Federativa do Brasil, Brasília, DF: Senado, 2011.

BRASIL. Lei n 9.099/95, Brasília, DF: Senado, 2011.

CAPPELLETTI, Mauro. O acesso à justiça e a função do jurista em nossa época. In: CONFERENCIA NACIONAL DA OAB, XII, 1990, Belo Horizonte. Anais. Brasília: OAB, 1991, p. 123-140.

CAPPELlETTI, Mauro; GARTH, Bryant. Acesso à justiça. Porto Alegre: Fabris, 2002.

CHIMENTI, Ricardo Cunha. Teoria e prática dos juizados especiais cíveis. São Paulo: Saraiva, 2003.

COUTINHO, Heliana M. de A.. O juiz agente político. Campinas: Copola, 1998. 
DINAMARCO, Cândido Rangel. Fundamentos do processo civil moderno. São Paulo: Revista dos Tribunais, 1986.

FADEL, Evandro. OAB recomenda 90 dos 1.210 cursos de Direito do País. O Estado de S. Paulo. Curitiba, 23 de novembro de 2011. Disponível em: $<$ http://www.estadao.com.br/ noticias/vida,oab-recomenda-90-dos-1210-cursos-de-direito-do-pais, 802016,0.htm $>$. Acesso em: 04 abr. 2012.

FALCÃO, Joaquim. Os advogados - a tentação monopolística. São Paulo: Folha de São Paulo, 1988.

FOUCAULT, Michel. A ordem do discurso. 9 ed. São Paulo: Loyola, 2003.

GRINOVER, Ada Pellegrini. Novas tendências do direito processual. Rio de Janeiro: Forense Universitária, 1990.

KELSEN, Hans. O que é Justiça? A justiça, o direito e a política no espelho da ciência. São Paulo: Martins Fontes, 1988.

MEDINA, Paulo Roberto de Golvêa. Direito Processual Constitucional. 3. ed. Rio de janeiro: Forense, 2005.

MORAIS, Lília Maia de; OLIVEIRA, Marcus Vinicius Amorim de. O Poder Judiciário e os desafios do Estado contemporâneo. Fortaleza: tribunal de justiça/ESMEC, 1998.

MORILAS, Luciana Romano. Técnicas argumentativas no discurso jurídico. In: Boletim da ABRALIN, v. 26, nº especial II, 2001.

NERY JUNIOR, Nelson. Princípios do processo civil na Constituição Federal. 7. ed.rev. e atual. com as Leis 10.352/2001 e 10.358/2001 - São Paulo: Editora Revista dos Tribunais, 2002.

REALE, Miguel. Lições preliminares de Direito. 19. ed. São Paulo: Saraiva, 1991.

TEIXEIRA, Sálvio de Figueiredo. "O aprimoramento do Processo Civil como garantia da cidadania”. In: TEIXEIRA, Sálvio de Figueiredo (coord). As garantias do cidadão na justiça. São Paulo: Saraiva, 1993.

WANTANABE, Kazuo. “Acesso à justiça e sociedade moderna”. In: GRINOVER, Ada Pellegrini; DINAMARCO, Candido Rangel; WANTANABE, Kazuo (coords.) Participação e Processo. São Paulo: Revista dos Tribunais, 1988.

WOLF, Mauro. Teorias da comunicação. 4.ed. Lisboa: Presença, 1995.

\section{CITIZEN AND FALSE LIBERTY BEFORE THE FUNDAMENTAL RIGHT OF ACCESS TO JUSTICE}

Abstract: This article aims to discuss the relationship between the fundamental right of access to justice, proclaimed by Brazil's Federal Constitution of 1988 and the prerogative of freedom that is given to the citizen in causes of low monetary value. It tries to analyze the fragility of the discourse of realization of justice without offering to the citizen the real understanding of the problem, along with the need for a Judiciary conscious of its constitutional, political and social functions.

Keywords: Access to justice. Freedom. Citizen. Judicial. Power relations. 